\title{
Pengembangan bahan ajar kewarganegaraan di Perguruan Tinggi Keagamaan Islam
}

\author{
Tubagus Ali Rachman Puja Kesuma a, , Sri Handayana ${ }^{\text {b, }}$, Deri Cicira ${ }^{c}$ \\ a Program Studi Tadris IPS IAIN Metro, Lampung, Indonesia

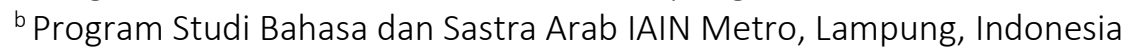 \\ c Program Studi Pendidikan Sejarah STKIP PGRI Bandar Lampung, Lampung, Indonesia
}

\begin{abstract}
ABSTRAK
Kewarganegaraan merupakan bagian dari mata kuliah wajib umum (MKWU) sesuai amanat konstitusi. Menghadapi ancaman tantangan hambatan dan gangguan (ATHG) negara Indonesia yang semakin kompleks, perguruan tinggi keagamaan islam sebagai bagian dari kekhasan pemerintahan Indonesia harus menunjukkan integrasi nilai-nilai keislaman, namun tetap memiliki satu kesatuan capaian pembelajaran mata kuliah dengan perguruan tinggi umum. Metode yang digunakan adalah Research and Development dengan teknik analisis data statistik deskriptif. Hasil penelitian menunjukkan bahwa materi kewarganegaraan dapat diintegrasikan dengan nilai-nilai ke-Islam-an sehingga dapat menunjang perkuliahannya di Perguruan Tinggi Keagamaan Islam. Adapun materi-materi yang dapat terintegrasi antara lain Negara dan sistem pemerintahan, demokrasi, serta hak asasi manusia. Bahan ajar sebagai produk dalam penelitian ini layak digunakan dengan persentase kelayakan $89.85 \%$.
\end{abstract}

\section{ABSTRACT}

Citizenship is part of the general compulsory subject (MKWU) according to the mandate of constitution. Facing the sophisticated threat of obstacles and disturbances in Indonesian, Islamic religious tertiary institutions as part of the uniqueness of the Indonesian government must demonstrate the integration of Islamic values, but still have a unified achievement of learning outcomes with general institutions. The method used is Research and Development with descriptive statistical data analysis techniques. The results showed that the material of citizenship could be integrated with Islamic values so that it can support its lectures at Islamic Religious Colleges. The materials that can integrate include the State and the government system, democracy, and human rights. Teaching material as a product in this study is feasible to use with a percentage of eligibility of $89.85 \%$.
Sejarah Artikel

Diterima : 3 Maret 2020

Disetujui : 5 Mei 2020

Kata kunci:

Bahan Ajar,

kewarganegaraan, nilainilai Keislaman, nilai-nilai

Keindonesiaan

\section{Keywords:}

Teaching Material

Civics Education

Islamic Values

Indonesian Values

\section{Pendahuluan}

Menghadapi tantangan kebangsaan sebagaimana termaktub dalam Ketetapan MPR nomor VI tahun 2001 tentang etika kehidupan berbangsa, pemerintahan Jokowi telah mencanangkan dan melaksanakan program Nawacita yang salah satu agendanya adalah revolusi karakter bangsa atau sering dikenal dengan "revolusi mental". Arah program tersebut salah satunya adalah kebijakan penataan kembali kurikulum pendidikan nasional dengan mengedepankan aspek pendidikan kewarganegaraan, yang menempatkan secara proporsional aspek pendidikan dengan pembentukan karakter bangsa seperti sejarah pembentukan bangsa, nilai-nilai cinta tanah air, patriotisme, semangat bela negara dan budi pekerti di dalam kurikulum pendidikan Indonesia. Sinergi pembentukan mental dan karakter bangsa dengan kurikulum pendidikan hingga saat ini merupakan cara yang efektif dan efisien bila dibandingkan dengan wajib militer. Hal serupa juga sukses dijalankan oleh negara-negara timur-tengah dengan konsep Tarbiyatul Al Watonniah/ Ta'limatul Muwattanah atau negara-negara barat dengan konsep Civic Education. Pendidikan kewarganegaraan di kawasan Asia Pasifik mengalami ketegangan dalam hal konsep-konsepnya. Misalnya di Taiwan, Meihui (2004) menunjukkan bahwa dalam wacana kewarganegaraan di Taiwan, ada ketegangan antara individu dan masyarakat, kebebasan dan ketertiban, keragaman 
dan keseragaman, Amerikanisasi dan lokalisasi, hak dan tanggung jawab, musyawarah dan kebajikan kewarganegaraan, kewarganegaraan universal dan kewarganegaraan yang berbeda, dan kewarganegaraan yang tetap dan kewarganegaraan yang fleksibel.

Malaysia dan Indonesia menjunjung tinggi Islam sebagai tradisi budaya pusat untuk menetapkan pilihan nilai-nilai budaya untuk ditransmisikan kepada kaum muda. Di Malaysia, kurikulum kewarganegaraan diwakili oleh Sejarah dalam pendidikan sekolah dan Tamadun Islam dan Tamadun Asia (TITAS), yaitu Peradaban Islam dan Peradaban Asia, dalam pendidikan universitas. Pertama bertujuan untuk menumbuhkan semacam "empati kesejarahan" yang akan memungkinkan pemahaman siswa kewarganegaraan untuk berlabuh di akar sejarah dan budaya negara. Kedua, bertujuan untuk meningkatkan kewarganegaraan pada konteks budaya negara yang didirikan di atas agama dan akar geografisnya (Bajunid, 2008). Demikian pula, kurikulum kewarganegaraan di Indonesia menekankan perlunya mengembangkan kompetensi pemahaman historis di kalangan siswa, sehingga mereka dapat "merekonstruksi masa lalu, membuat makna dari masa kini dan memprediksi masa depan"(Fearnley-Sander \& Yulaelawati, 2008).

Sejalan dengan hal tersebut, keberadaan perguruan tinggi keagamaan Islam di bawah naungan kementerian agama Republik Indonesia merupakan keunikan tersendiri dalam pemerintahan Indonesia sebagaimana tercantum dalam pasal 7 ayat (4) Undang-Undang Nomor 12 Tahun 2012 tentang Pendidikan Tinggi. Agenda revolusi mental dalam Nawacita dilaksanakan berdasarkan amanat pasal 35 ayat (3) Undang-undang nomor 12 tahun 2012 tentang pendidikan tinggi dimana setiap kurikulum pendidikan tinggi wajib memuat mata kuliah Agama, Pancasila, kewarganegaraan, dan Bahasa Indonesia. Hal ini juga diperkuat dengan diterbitkannya Peraturan Presiden Republik Indonesia Nomor 8 Tahun 2012 tentang Kerangka Kualifikasi Nasional Indonesia, yang menegaskan bahwa capaian pembelajaran umum bagi semua jenjang pendidikan antara lain adalah berperan sebagai warga negara yang bangga dan cinta tanah air serta mendukung perdamaian dunia, menghargai keanekaragaman budaya, menjunjung tinggi penegakan hukum serta memiliki semangat untuk mendahulukan kepentingan bangsa dan masyarakat luas. Indikator-indikator tersebut sesungguhnya adalah tujuan substantif dari mata kuliah Pendidikan Kewarganegaraan (Kementerian Riset Teknologi dan Pendidikan Tinggi, 2017).

Pendidikan kewarganegaraan juga merupakan wujud keikutsertaan warga negara dalam bela Negara adalah keikutsertaan warga negara dalam Pendidikan Kewarganegaraan yang diamanatkan Pasal 9 ayat (2) Undang-Undang nomor 3 Tahun 2002 tentang Pertahanan Negara. Hal ini menyiratkan bahwa materi pendidikan kewarganegaraan harus dipahami oleh seluruh komponen bangsa terutama generasi muda dengan disesuaikan dengan latar belakang suku, agama, dan atau bahkan ras. Hal senada juga ditegaskan dalam Peraturan Menteri Riset, Teknologi dan Pendidikan Tinggi nomor 44 tahun 2015 tentang Standar Nasional Pendidikan Tinggi. Implementasinya adalah surat edaran Direktorat Jenderal Pembelajaran dan Kemahasiswaan nomor 435/B/SE/2016 tentang himbauan penggunaan bahan ajar mata kuliah wajib umum yang telah di revitalisasi untuk menunjang agenda revolusi mental, sebagai salah satu sumber bahan ajar dalam proses pembelajaran di perguruan tinggi.

Pendidikan kewarganegaraan sebagai bagian dari dimensi kurikuler di kurikulum setiap jenjang pendidikan memiliki muatan tiga dimensi pokok pembelajaran yaitu sebagai pembelajaran kurikuler yang include dalam kurikulum seperti layaknya mata kuliah lain sebagai pembelajaran sosial politik yang membelajarkan hubungan warga negara dengan negara, ataupun dengan sesama warga negara dan sebagai program akademik yang memiliki nilai dan prosedur edukatif dalam membelajarkannya (Winataputra, 2001).

Kerr (1999) menambahkan bahwa "kewarganegaraan mencakup berbagai kajian seperti citizenship, civics, ilmu pengetahuan sosial, life skills, pendidikan moral, sejarah, geografi, 
ekonomi, hukum, politik, lingkungan hidup, dan pendidikan nilai" (hal. 2). Dalam kaitannya dengan pendidikan kewarganegaraan sebagai mata kuliah wajib umum di pendidikan tinggi khususnya keagamaan Islam, maka substansi materi pembelajarannya pun perlu sinergi dengan kajian keIslam-an. Hal tersebut merupakan kekhasan yang membedakannya dengan perguruan tinggi umum. Kajian ke-Islam-an yang dimaksud adalah nilai-nilai ke-Islam-an dan perkembangan sosionasionalisme di Indonesia. Merespons kebutuhan akan bahan/ materi ajar kewarganegaraan dalam rangka meningkatkan pendidikan karakter bangsa Indonesia yang berlandaskan nilai keIslam-an maka kehadiran bahan ajar pendidikan kewarganegaraan yang di dalamnya terintegrasi dengan nilai-nilai keislaman dan keindonesiaan merupakan terobosan baru untuk menanggulangi ancaman, tantangan, hambatan dan gangguan kebangsaan masyarakat Indonesia.

Berbagai penelitian yang membahas revolusi mental/ karakter bangsa Indonesia melalui pengembangan materi Pendidikan Kewarganegaraan telah banyak dilakukan. Namun, belum menyentuh substansi integrasi materi Kewarganegaraan dengan ke-Islam-an. Ketika MPR RI membumikan "Empat Pilar" sebagai bentuk pengembangan kembali karakter bangsa, Winarno (2015) merevitalisasi materi pembelajaran kewarganegaraan dengan menerbitkan buku ajar yang berjudul "pendidikan kewarganegaraan untuk perguruan tinggi" dengan pengembangan materi merujuk pada Surat Keputusan Dirjen Dikti No. 43 Tahun 2006. Secara substansi, materi pokok tidak mengubah bab-bab secara mendasar. Perubahan dilakukan pada hal-hal konseptual yang bernilai dan dapat diintegrasikan dengan empat pilar kebangsaan yaitu Pancasila sebagai ideologi dan dasar negara, UUD NRI tahun 1945 sebagai konstitusi negara, NKRI sebagai bentuk negara, dan Bhinneka Tunggal Ika sebagai semboyan negara (Winarno, 2015).

Selanjutnya, Hadin dan Fahlevi (2016) pernah merumuskan pengembangan bahan ajar Pendidikan Kewarganegaraan yang terintegrasi dengan pendidikan antikorupsi sebagai bentuk upaya pemberantasan KKN yang sampai hari ini menjadi pandemi moral bangsa Indonesia. Materi ajarnya menitikberatkan kepada pengetahuan (knowledge), keterampilan-keterampilan menganalisis dan berfikir kritis (analytical \& critical thinking) yang diharapkan membentuk keterampilan-keterampilan experiential learning (hal. 162-172).

LP3M Universitas Muhammadiyah Yogyakarta hakikatnya juga telah berupaya melakukan pengintegrasian tersebut melalui penerbitan buku ajar Pendidikan Kewarganegaraan yang di dalamnya termuat nilai-nilai keislaman dan kemuhammadiyahan (Chamim, 2003). Buku ajar ini menawarkan materi PKn yang berisi materi: masyarakat madani, pemerintahan yang bersih dan demokratis, transformasi nilai-nilai demokrasi, transformasi nilai-nilai Islam dalam keluarga, transformasi nilai-nilai Islam dalam masyarakat, Islam musyawarah dan demokrasi, HAM dalam perspektif Islam, sistem ekonomi Islam, dan prinsip-prinsip kepemimpinan Islam (Arif \& Aulia, 2017).

Dalam konteks penelitian ini, ketiga kajian-kajian tersebut dijadikan dasar dalam pengembangan bahan ajar dalam penelitian ini, sehingga memiliki cakupan yang lebih luas untuk di pergunakan di Perguruan Tinggi Keagamaan Islam di bawah naungan kementerian Agama Republik Indonesia, serta sesuai dengan kebijakan revitalisasi materi kewarganegaraan yang diterbitkan Kemenristekdikti pada tahun 2016. Berdasarkan kajian-kajian penelitian terdahulu, bahan ajar merupakan salah satu bagian terpenting dari proses pembelajaran dan menentukan sukses atau gagalnya proses tersebut. Adanya bahan ajar akan membuat pembelajaran memiliki acuan dasar materi yang akan dibelajarkan. Adanya bahan ajar juga akan menstandarisasi pembelajaran pendidikan kewarganegaraan khususnya di perguruan tinggi keagamaan Islam yang selama ini di kembangkan oleh masing-masing dosen pengampu. 
Dalam rangka mencapai CPL mata kuliah kewarganegaraan, maka Direktorat Jenderal Pembelajaran dan Kemahasiswaan Kemenristekdikti hakikatnya telah meramu materi pendidikan kewarganegaraan di perguruan tinggi yang mencerminkan keutuhan pemahaman peserta didik terhadap keseluruhan materi yang telah dibelajarkan (Direktorat Jenderal Pembelajaran dan Kemahasiswaan, 2016). Untuk mewujudkan kekhasan penyelenggaraan pembelajaran kewarganegaraan di Perguruan Tinggi Keagamaan Islam, maka pendidikan kewarganegaraan di perguruan tinggi sebagai dimensi pembelajaran kurikuler, social politik, dan program akademik, dituntut menyesuaikan substansi kajiannya dengan menyinergikan dengan nilai-nilai ke-Islam-an dalam rangka membentuk pribadi generasi muda muslim yang baik dan cerdas (good and smart moslem's). Pernong sebagaimana dikutip Kesuma (2017) berpendapat bahwa Islam merupakan agama wahyu dari Allah yang merupakan causa prima. Ajaran Islam terjabarkan menjadi sebuah dasar dari segala bentuk pandangan hidup/falsafah, serta menjadi sumber dari segala kebenaran (hal. 245). Maka, pengintegrasiannya dalam materi kewarganegaraan merupakan upaya yang strategis dalam mewujudkan moderasi beragama. Hal ini juga merupakan bagian dari usaha dunia pendidikan untuk menangkal radikalisme dan terorisme yang dewasa ini melekat sebagai sebuah stereotype bagi umat Islam.

\section{Metode}

Pengembangan bahan ajar Pendidikan Kewarganegaraan di PTKI dalam penelitian ini menggunakan metode R\&D dengan membatasi langkah penelitian dan pengembangan hanya sampai langkah ke Sembilan yaitu revisi produk. Gambar langkah-langkah pengembangan produk dapat dilihat dengan jelas pada gambar di bawah ini.

Gambar 1

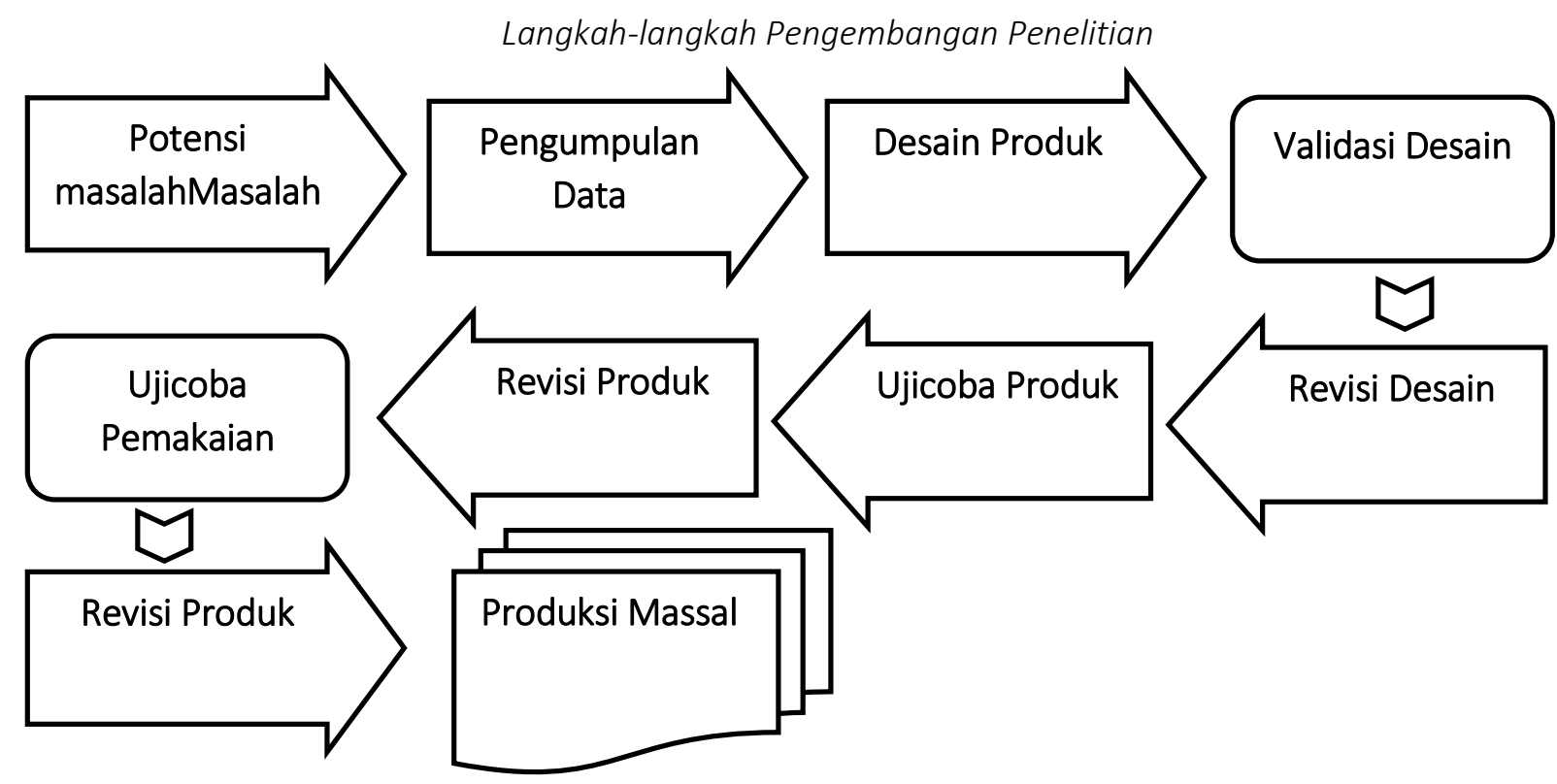

Sumber: Sugiyono (2012).

Pada penelitian pengembangan ini, ada dua subjek penelitian yaitu expert judgement atau ahli/ pakar dan user yaitu pengguna produk. Analisis data yang di gunakan dalam penelitian ini menggunakan statistik deskriptif dengan rumus persentase untuk mengukur kelayakan produk saat uji coba. 


\section{Hasil dan Pembahasan}

\section{Analisis Kebutuhan Dosen dan Mahasiswa}

Analisis kebutuhan dosen pengampu mata kuliah Pendidikan Kewarganegaraan terhadap bahan ajar Pendidikan Kewarganegaraan di PTKI dilakukan untuk memperoleh karakteristik materi keagamaan Islam yang cocok dan dapat bersinergi dengan materi Pendidikan Kewarganegaraan yang telah dirumuskan Direktorat Jenderal Pembelajaran dan Kemahasiswaan Kementerian Riset Teknologi dan Pendidikan Tinggi dan di edarkan sesuai himbauan nomor: 435/B/SE/2016.

Angket analisis kebutuhan dosen diberikan kepada pengampu mata kuliah Pendidikan Kewarganegaraan yaitu Ibu Nety Hermawati, MH dan Susi Yulianti, MH dari IAIN Metro. Hasil analisis kebutuhan pada dosen pengampu mata kuliah Pendidikan Kewarganegaraan menunjukkan bahwa pembelajaran kewarganegaraan harus lebih menekankan pada nalar mahasiswa terhadap pemahaman/ pemecahan permasalahan kehidupan bermasyarakat berbangsa dan bernegara (problem solving) yang diimplementasikan dalam sebuah project citizen. Materi keislaman sebagai ciri khas PTKIN memang harus dimunculkan pada perkuliahan/ pembelajaran. Hal ini bertujuan memberikan pengetahuan dan pemahaman pada mahasiswa tentang peran Islam dalam sejarah perjuangan kemerdekaan Indonesia, dan pemahaman nilainilai kajian Islam yang universal, toleran, cinta damai, dan rahmatan lil alamin dalam kehidupan bermasyarakat, berbangsa dan bernegara. Pemahaman ini akan semakin meneguhkan keimanan sekaligus memupuk jiwa nasionalisme dan patriotisme mahasiswa, sesuai dengan konsep Hubbul Wathon Minal Iman.

Angket analisis kebutuhan dosen diberikan kepada 16 orang mahasiswa semester 1 (ganjil) tahun akademik 2018/2019 yang tersebar di 8 program studi (PAI, TBI, PGMI, PBA, PIAUD, TIPS, TMTK, TBIO) pada Fakultas Tarbiyah dan Ilmu Keguruan IAIN Metro. Hasil angket menunjukkan bahwa dalam perkuliahan pendidikan kewarganegaraan sulit dipahami karena materi tersebut luas, abstrak, dan sulit untuk diaplikasikan dalam pengalaman belajar mahasiswa. Sajian materi belum menuntun mahasiswa merefleksikan diri dalam kehidupan bermasyarakat, berbangsa dan bernegara secara nyata. Materi pendidikan Kewarganegaraan memiliki potensi yang cukup kuat untuk diintegrasikan dengan kajian ke-Islam-an sebagai jati diri PTKI. Hakikatnya nilai-nilai Islam sangat erat melekat dalam kehidupan bermasyarakat, berbangsa dan bernegara. Materi negara dan pemerintahan, identitas nasional, hak asasi manusia, dan demokrasi merupakan beberapa materi yang juga dibahas dalam Islam sehingga mempunyai potensi untuk dipadukan. Perpaduan ini akan membentuk materi yang mampu memperkuat karakter mahasiswa muslim yang cerdas, moderat, dan toleran dalam menyikapi isu-isu disintegrasi bangsa yang banyak melibatkan unsur SARA.

\section{Penyusunan Prototype Bahan Ajar}

\section{Aspek Materi}

Penelitian ini menghasilkan suatu produk bahan ajar yang di berjudul Pendidikan Kewarganegaraan "be good and smart moslem". Menilik pada kekhasannya sebagai perguruan tinggi berbasis keagamaan Islam maka dalam perkuliahan pendidikan Kewarganegaraan juga diperlukan buku ajar pendamping yang mencerminkan sinergi materi kewarganegaraan dengan kajian ke-Islam-an selain buku ajar yang diterbitkan Direktorat Jenderal Pembelajaran dan Kemahasiswaan Kemenristekdikti tahun 2016. Pada kenyataannya memang beberapa konten materi pendidikan Kewarganegaraan juga selaras, bersinergi bahkan merujuk pada nilai kajian Islam. Hal ini tentu akan membuka wawasan mahasiswa terhadap hubungan kehidupan beragama dan bernegara sehingga mampu memupuk rasa nasionalisme dan patriotisme serta persatuan 
yang mendalam. Adapun materi-materi Pendidikan Kewarganegaraan yang berpotensi diintegrasikan dengan kajian keislaman antara lain:

Tabel 1

Integrasi Materi Kewarganegaraan dengan Kajian Keislaman

\begin{tabular}{|c|c|c|}
\hline \multirow{2}{*}{$\begin{array}{l}\text { Materi Bahan Ajar } \\
\text { Kewarganegaraan }\end{array}$} & \multicolumn{2}{|c|}{ Desain Pengembangan Materi } \\
\hline & Kajian Pokok & Kajian Materi Ke-Islam-an \\
\hline \multirow{4}{*}{$\begin{array}{l}\text { Negara dan Sistem } \\
\text { Pemerintahan }\end{array}$} & Latar belakang, definisi, unsur negara & Negara dalam tinjauan normatif dan \\
\hline & Negara dan sistem pemerintahan & historis Islam \\
\hline & Trias Politica & Relasi agama dengan negara \\
\hline & Sifat, fungsi dan kekuatan negara & \\
\hline \multirow[t]{5}{*}{ Demokrasi } & Pengertian, Manfaat, Dan Makna & Kajian Teologis Demokrasi \\
\hline & Demokrasi & Relasi ajaran Islam dengan kajian \\
\hline & Kriteria, Prinsip Dan Nilai demokrasi & demokrasi \\
\hline & Perjalanan demokrasi di Indonesia & \\
\hline & Pendidikan Demokrasi & \\
\hline \multirow[t]{3}{*}{ Hak Asasi Manusia } & Sejarah, definisi, dan pokok HAM & Pemikiran HAM secara intelaktual, \\
\hline & $\begin{array}{l}\text { Macam-macam HAM } \\
\text { Pelanggaran dan nengadilan HAM }\end{array}$ & $\begin{array}{l}\text { emosional dan spiritual } \\
\text { HAM dalam Al-Ouran dan Al-Hadist }\end{array}$ \\
\hline & & HAM dalam piagam Madinah \\
\hline
\end{tabular}

Sumber: Data hasil penelitian, 2019.

\section{Aspek Bahasa Dan Tata Tulis}

Bahasa dalam buku ajar Pendidikan Kewarganegaraan "Be Good and Smart Moslem" menggunakan Bahasa Indonesia dengan berpedoman pada Pedoman Umum Ejaan Bahasa Indonesia (PUEBI) dengan berpedoman pada Peraturan Menteri Pendidikan dan Kebudayaan Nomor 50 Tahun 2015 tentang Pedoman Umum Ejaan Bahasa Indonesia. Kata atau kalimat bahasa asing tetap ditulis dengan bahasa aslinya dengan dicetak miring (italic) dan bila lebih dari 4 baris maka dijadikan 1 spasi. Penulisan menggunakan model huruf times new roman dengan ukuran (font) 12, spasi yang digunakan adalah 1,5 sedangkan untuk tulisan dalam tabel menggunakan spasi 1. Gaya selikung rujukan/ referensi secara umum menggunakan body note, namun tetap mempertimbangkan foot note untuk menjelaskan hal lain yang masih berkaitan dengan bahasan secara terperinci.

\section{Aspek Media dan Grafika}

Aspek media dan grafika dibuat sedemikian rupa dengan design secara abstrak sehingga mewakili pluralitas materi yang disajikan. Warna dominan putih pada cover menunjukkan tujuan yang suci dari perkuliahan Pendidikan Kewarganegaraan yaitu mewujudkan generasi penerus bangsa yang baik dan cerdas (good and smart citizens). Warna orange menunjukkan kenyamanan hidup bermasyarakat berbangsa dan bernegara dengan sikap yang toleran walaupun beraneka ragam suku, agama dan ras. Warna hijau Tosca menunjukkan keceriaan dengan harapan pembelajaran pendidikan kewarganegaraan akan berjalan dengan aktif efektif dan menyenangkan.

Kalimat be a good and smart moslem, merupakan modifikasi dari tujuan pendidikan kewarganegaraan pada umumnya yaitu good and smart citizen, karena buku ini digunakan sebagai pedoman perkuliahan kewarganegaraan di perguruan tinggi keagamaan Islam. Sama halnya dengan kalimat Hubbul Wathon Minal Iman menunjukkan bahwa antara kajian agama dan negara memiliki sinergi yang kuat untuk membentuk semangat nasionalisme dan patriotisme warga negara. Paragraf di cover belakang mendeskripsikan urgensi mata kuliah di perguruan tinggi keagamaan Islam serta tujuan penyelenggaraannya sehingga memotivasi penulis untuk membuat buku ajar ini. Kalimat "bhinneka tunggal ika tan hana dharma mangrwa" menunjukkan semboyan 
bangsa sebagai modal persatuan dan kesatuan bangsa Indonesia yang berbeda suku, agama dan ras.

Gambar 2

Prototype Cover Buku Ajar Kewarganegaraan "Be Good and Smart Moslem's"

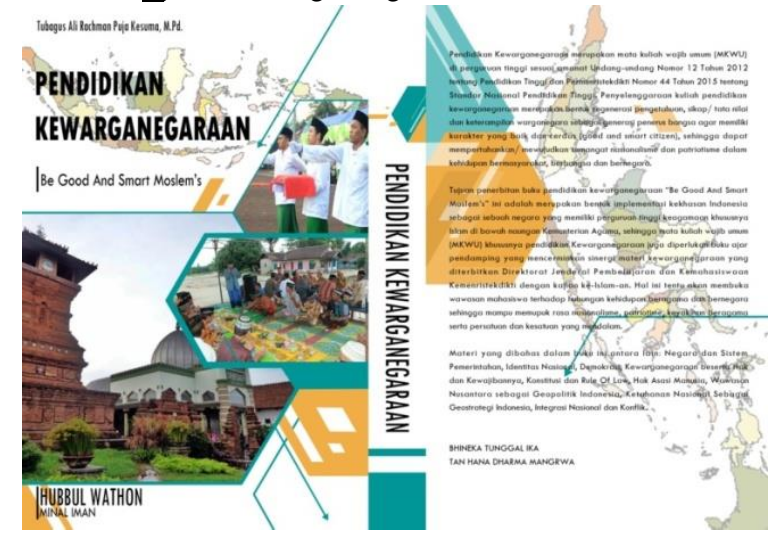

Background wilayah Indonesia di cover depan dan belakang merupakan cerminan wilayah teritorial negara kesatuan republik Indonesia yang wajib dipertahankan dengan segenap daya dan upaya termasuk melalui penyelenggaraan mata kuliah pendidikan Kewarganegaraan. Gambar Masjid Menara Kudus dan kenduri mencerminkan akulturasi antara agama Islam dengan budaya masyarakat sebelumnya, ini menunjukkan bahwa Islam adalah yang rahmatan lil alamin. Gambar santri yang melaksanakan upacara bendera mewakili umat Islam yang menjunjung tinggi rasa nasionalisme dan patriotisme.

\section{Konsep Integrasi Materi Pendidikan Kewarganegaraan Dengan Nilai Keislaman}

Pengembangan materi Pendidikan Kewarganegaraan yang terintegrasi dengan nilai-nilai keIslam-an dalam penelitian ini bukan dimaksudkan untuk menyalahi kurikulum pendidikan tinggi, merendahkan kontribusi agama lain dalam kehidupan berbangsa dan bernegara, atau bahkan mengklaim superioritas peran Islam dalam pemerintahan di Indonesia. Justru, penelitian yang menghasilkan produk buku ajar "Pendidikan Kewarganegaraan Be Good and Smart Moslems" ini merupakan upaya/ ijtihad peneliti dalam mewujudkan kekhasan Perguruan Tinggi Keagamaan Islam (PTKI) dengan tetap menjunjung tinggi kaidah nilai-nilai ke-Indonesia-an yang diamanatkan kurikulum. Hal ini sejalan dengan 3 (tiga) capaian pembelajaran lulusan (CPL) mata kuliah kewarganegaraan yang dirumuskan Kemenristekdikti yaitu: pertama, pengembangan sikap positif dan menampilkan perilaku mahasiswa yang mendukung semangat kebangsaan dan cinta tanah air. Semangat kebangsaan dan cinta tanah air sangat dianjurkan dalam ajaran Islam untuk menumbuh kembangkan jiwa nasionalisme dan patriotisme mahasiswa, sesuai dengan konsep Hubbul Wathon Minal Iman. Kedua, pengembangan sikap positif dan menampilkan perilaku yang mendukung demokrasi berkeadaban. Mewujudkan keberadaban dalam berdemokrasi itu merupakan bagian dari kajian Islam, karena Islam sangat menjunjung tinggi as-Syura (musyawarah), al-'Adalah (Keadilan), al-Musawah (kesejajaran), al-Amanah (Kepercayaan), alMasuliyyah (tanggung jawab), dan al-Hurriyyah (kebebasan) yang menjadi dasar/ prinsip utama keberadaban penyelenggaraan demokrasi. Ketiga, pengembangan sikap positif dan menampilkan perilaku yang mendukung kesadaran hukum dan toleransi dalam keberagaman. Ajaran Islam juga sangat menjunjung tinggi hukum dan toleransi, serta sesuai dengan segala macam bentuk perkembangan zaman dan zonasi wilayah. Hal ini sebagai bentuk pengejewantahan nilai-nilai Islam yang universal, toleran, cinta damai, dan rahmatan lil alamin dalam kehidupan bermasyarakat, berbangsa dan bernegara. 
Ketiga CPL ini juga sejalan dengan teori dari Kerr, yang mengungkapkan bahwa kewarganegaraan tidak semata-mata menitik beratkan pada kajian citizenship, civics, ilmu pengetahuan sosial, life skills, sejarah, geografi, ekonomi, hukum, politik, dan lingkungan hidup. Namun kewarganegaraan juga mengkaji pendidikan nilai dan moral dimana keduanya di dasarkan pada kaidah-kaidah keagamaan.

Perwujudan kekhasan ini merupakan bagian dari usaha peneliti untuk mewujudkan moderasi beragama guna menangkal radikalisme dan terorisme yang dewasa ini melekat sebagai sebuah stereotype bagi umat Islam. Sinergi pemahaman nilai-nilai ke-Islam-an dengan keIndonesia-an bagi umat Muslim akan menciptakan kehidupan yang harmonis di tengah pluralitas suku, agama dan ras (SARA). Adapun konsep pengembangan materi Pendidikan Kewarganegaraan yang terintegrasi dengan nilai-nilai ke-Islam-an dalam dijabarkan sebagai berikut:

\section{Konsep Pengembangan Materi Negara dan Sistem Pemerintahan}

Materi negara dan sistem pemerintahan di kembangkan dengan pengintegrasian kajian normatif dan historis negara dalam Islam, serta relasi negara dengan agama. Integrasi materimateri tersebut dalam materi negara dan sistem pemerintahan bertujuan untuk deradikalisasi pemahaman beragama dan bernegara di kalangan mahasiswa. Pertama, Kajian normatif dan historis memberikan landasan konsep negara dalam Islam. Kajian historis memberikan gambaran bahwa Madinah (pada masa Rasulullah Shallallahu'alaihi wa Sallam) dapat dianggap sebagai sebuah negara karena memenuhi unsur sebuah negara yakni masyarakat, wilayah dan pemerintahan yang berdaulat. Berbeda dengan agama lainnya, dalam kacamata historis Islam adalah agama yang sejak awal munculnya selalu bersentuhan dengan masalah politik dan kenegaraan. Strategi nabi Muhammad Shallallahu'alaihi wa Sallam ketika mengelola Madinah sangat tegas menunjukkan perpaduan harmonis antara agama dan negara. Walaupun demikian, peran ganda Nabi serta penyataan bahwa negara menjadi sarana untuk merealisasikan wahyu Allah membuat para tokoh Muslim (al Mawardi, al Ghazali, Ibn Taimiyah) berbeda pendapat tentang landasan pendirian negara dalam Islam. Perbedaan inilah yang membuat praktik ketatanegaraan yang berbeda sepeninggal Rasulullulah, baik dengan konsep Imamah (Syiah) ataupun khilafah (Sunni). Sekalipun masa Khulafaurrasyidin dipandang kelompok Sunni sebagai model pemerintahan ideal sepanjang sejarah Islam, namun realitas sepanjang pemerintahan Bani Umayyah (661-750) dan Bani Abbasiyah (750-1258) amat berbeda. Pemerintahan Islam berbentuk imperium di mana kepentingan serta karakter pemimpinnya tidak begitu menunjukkan negara Islam yang ideal.

Secara kajian normatif, pemimpin suatu negara mempunyai fungsi religius dan politis dengan berbagai kekhasan praktik ketatanegaraannya. Islam dalam politik/ kenegaraan merupakan hal yang niscaya, karena persoalan keduniawian termasuk ketatanegaraan ada pedomannya dalam Islam (Natsir, 1961). Kedua konsep tersebut legal untuk diaplikasikan karena, memang Allah tidak mendeskripsikan spesifikasi ketatanegaraan secara rinci, yang terpenting adalah penyelenggaraan ketatanegaraan tidak menyimpang dari ketauhidan. Seiring dengan tatacara negara memperoleh kemerdekaannya, maka perkembangan teori politik dan kepemimpinan pun berkembang termasuk di Indonesia. Ketiadaan ayat Alquran dan Sunnah yang secara baku menjelaskan konsep negara dalam Islam. Pada akhirnya kenyataan ini melahirkan ragam penafsiran tentang negara. Kelompok pertama menekankan aspek formalistis. Kelompok ini ingin mengarahkan Islam menjadi suatu bentuk politik hingga menjadi negara Islam. Sedangkan kelompok lain lebih menonjolkan aspek substantif yakni tegaknya nilai-nilai etis seperti keadilan, kesetaraan dan persaudaraan. Berbagai macam praktik kenegaraan di negara-negara yang berpenduduk mayoritas Muslim hingga saat ini merefleksikan penelaahan pemikiran atau ijtihad dalam upaya memaksimalkan fungsi dan peranan negara sebagai instrument bagi pemenuhan 
kepentingan dan kesejahteraan rakyat baik lahir maupun batin. Pada dasarnya Islam tidak menentukan bentuk negara. Keberadaan ayat-ayat Alquran yang lebih terfokus kepada prinsip sebuah negara seperti musyawarah, keadilan dan sebagainya membuka peluang yang luas untuk perambahan intelektual dalam menentukan model dan format negara sesuai dengan masa dan kondisi sosial masyarakat. Ketiadaan format baku sebuah negara dalam Islam juga mengandung pemahaman bahwa tidak peduli apapun bentuk negaranya selama prinsip dan ajaran Islam dapat diimplementasikan, maka hal tersebut tidak menjadi masalah.

Kajian ini akan memperkuat pemahaman bagi mahasiswa yang kuliah di Perguruan Tinggi Keagamaan Islam, bahwa bentuk dan sistem pemerintahan yang diterapkan di Indonesia bukan didasarkan pada ideologi yang kafir. Ketiadaan ayat dan Sunnah baku yang menjelaskan praktik ketatanegaraan membuktikan kuasa besar Allah Subhanahu wa Ta'ala, dimana menusia ditempatkan sebagai makhluk dengan derajat lebih tinggi dibanding yang lainnya. Adanya akal pikiran, nafsu dan perasaan merupakan keleluasaan yang diberikan Allah Subhanahu wa Ta'ala untuk mengelola ketatanegaraan sebaik mungkin sesuai dengan geopolitik dan geostrateginya.

Kedua, materi relasi agama dan negara memberikan penjabaran tentang hubungan penyelenggaraan Islam dan politik dalam praktik ketatanegaraan modern. Relasi itu terbagi menjadi 3 (tiga) paradigma dengan kekhasan masing-masing. Pertama, paradigma integralistik yang menganggap bahwa agama dan negara adalah sebuah kesatuan yang tidak terpisahkan. Kelompok ini memandang bahwa agama dan negara adalah ibarat dua sisi dari satu keping mata uang, satu dengan lainnya tidak dapat dipisahkan. Dengan kata lain, agama adalah lembaga politik sekaligus lembaga agama. Hal ini seperti dicontohkan Saudi Arabia yang menjadikan Al-Quran sebagai UUD (Sadzali, 1990). Kehidupan bernegara diatur berdasarkan prinsip keagamaan, dan dari sini muncullah istilah Islam ad-din wa ad-daulah. Kedua, paradigma sekuler yang menganggap ketatanegaraan adalah urusan antar manusia sementara agama merupakan hubungan manusia dalam dimensi individual dengan Tuhannya. Agama hanya berkisar tentang hubungan manusia dengan tuhannya (tauhid) dan pembinaan akhlak dan moral manusia dalam berbagai aspek kehidupan. Dengan demikian, norma hukum ditetapkan berdasarkan kesepakatan manusia bukan firman Tuhan dan tidak menutup kemungkinan bertentangan dengan ajaran agama. Uniknya, sekalipun negara-negara penganut paham sekuler memisahkan agama dan negara, pada umumnya mereka tidak ikut campur dalam urusan agama dan memberikan kebebasan kepada warga negaranya untuk memeluk agama yang diyakini. Ketiga, paradigma simbiotik yang menganggap negara dan agama memiliki hubungan timbal balik dan saling membutuhkan. Agama membutuhkan dukungan negara untuk menjaga eksistensinya. Sedangkan negara membutuhkan agama untuk memenuhi kebutuhan spiritual serta membina moral serta etika. Negara tidak harus dijalankan berdasarkan norma agama. Fungsi agama lebih ditekankan ke pengawalan agar realitas sosial politik tidak keluar dari jalur yang seharusnya.

Pada kajian ini, mahasiswa diberikan pemahaman bahwa Indonesia sebagai penganut paradigma simbiotik tidak serta-merta mengesampingkan urusan negara dengan agama. Walaupun demikian Indonesia juga tidak bisa menjadi negara agama karena pluralitas keagamaan masyarakatnya. Kondisi ini menempatkan agama dengan negara pada posisi saling membutuhkan, dan toleransi merupakan kunci untuk menjaga keutuhan Negara Kesatuan Republik Indonesia.

\section{Konsep Pengembangan Materi Demokrasi}

Materi demokrasi di kembangkan dengan pengintegrasian kajian teologis dan relasi Islam dengan demokrasi. Integrasi materi-materi tersebut dalam demokrasi bertujuan untuk memberikan pemahaman kepada mahasiswa bahwa hakikatnya berdemokrasi bukanlah sistem politik, bentuk pemerintahan ataupun sikap hidup yang bidah untuk dijalankan. Menurut Kesuma 
(2017), pemahaman ini akan memberikan kedewasaan berdemokrasi mahasiswa yang salah satu indikatornya adalah lunturnya politik suku dan keagamaan pada pemilihan pemimpin tertentu (hal. 211). Pertama, menurut Zainuddin (2011), secara kajian teologis Islam dan demokrasi memang berbeda Islam berdasar atas ketetapan Allah yang tidak bisa di tawar lagi sedangkan demokrasi berdasarkan atas olah pikir manusia yang cenderung bersifat dinamis, namun tidak ada halangan bagi keduanya untuk berdampingan (hal. 5). Dalam hal akuntabilitas, kepemimpinan pemerintahan Islam tetap mengutamakan kepentingan rakyat dengan memperhatikan kesejahteraan rakyat (dunia dan akhirat). Walaupun demikian secara teologis tetap bertanggung jawab kepada Allah dan Wahyu-Nya serta tuntunan Sunnah Rasul. Kehendak mayoritas rakyat sekalipun belum tentu mengubah pertanggung-jawaban terhadap Allah. Hal ini mencerminkan bahwa pemerintahan Islam menjunjung tinggi kedaulatan Allah, sedangkan demokrasi pada umumnya mengikuti kehendak rakyat penuh.

Kedua, kajian relasi Islam dengan demokrasi merupakan pembuktian keselarasan prinsip diantara keduanya. Prinsip itu yaitu as-Syura (Musyawarah) yang merupakan pedoman atau prinsip untuk membuat/ mengambil suatu keputusan, al-'Adalah (Keadilan) yang merupakan pedoman dalam menciptakan kekuasaan pemerintahan yang ideal, baik dan bersih, al-Musawah (Kesejajaran) merupakan pedoman dalam membatasi kekuasaan seorang pemimpin agar tidak bersikap otoriter, al-Amanah (kepercayaan) yang merupakan wujud kewajiban yang harus dilaksanakan, al-Masuliyyah (tanggung Jawab) yang merupakan pertanggung jawaban secara ikhlas dan tawakal, dan al-Hurriyyah (kebebasan) yang merupakan hak untuk mengolah akal pikiran dan perasaan serta nafsunya.

\section{Konsep Pengembangan Materi Hak Asasi Manusia}

Materi hak asasi manusia di kembangkan dengan pengintegrasian kajian pemikiran HAM secara intelektual-emosional-spiritual, HAM dalam Al-Quran dan Hadis, dan HAM dalam piagam Madinah. Integrasi materi-materi tersebut dalam hak asasi manusia akan memicu antusiasme mahasiswa dalam penghormatan, penegakan, dan penghargaannya dalam kehidupan sehari-hari mereka, karena merupakan bagian dari penegakan syariat Islam. Pertama, pemikiran hak asasi manusia secara intelektual-emosional-spiritual menjelaskan bahwa hak asasi manusia hal yang alamiah melekat pada fitrah manusia, dan dasarnya pun pada kemampuan/ bakat/ kodrat manusia. Hak asasi manusia otomatis ada dalam diri manusia karena kodratnya sebagai makhluk Tuhan Yang Maha Kuasa. Hak asasi manusia harus sejalan dengan nilai dan konsep spiritual karena muncul sebagai fitrah manusia, yang hal ini memiliki konsekuensi bahwa hanya manusia yang beragama yang dapat menuntut pengakuan, penghormatan, penegakan dan perlindungan hak asasi manusia. Hak asasi manusia harus dipahami secara integral dan holistic yang meliputi aspek intelektual, emosional dan spiritual. Pemahaman hak asasi manusia yang tanpa dilandasi dengan konsep spiritualitas hanya akan menjadi alat untuk memupuk paham sekularisme, liberalisme, dan bahkan komunisme, serta menjadikan manusia justru lebih jauh dari Tuhan Yang Maha Esa.

Hak asasi manusia tidak bisa dilepaskan dalam konsep ke-Tuhan-an, karena manusia sendiri ada karena Allah Yang Maha Pencipta. Tentu sebagai hamba Allah kita wajib bertakwa dengan melaksanakan perintah dan menjauhi larangan-Nya. Semua aspek kehidupan di alam semesta selalu menempatkan Tuhan pada posisi sentral (theocentric), sedangkan dalam konsep sekuler berpandangan bahwa manusia yang menempati posisi sentral (antroposentris). Indonesia tidak bisa memisahkan nilai ketuhanan dan kepentingan individu dan atau negara/ pemerintah dalam pemahaman HAM layaknya negara sekuler karena nilai ketuhanan yang menjadi dasar kita dalam bertindak dan berperilaku.

Kedua, materi hak asasi manusia dalam al-Quran dan Hadis merupakan bentuk pengakuan, penghormatan, penegakan hak asasi manusia. Menurut Islam merupakan dasar perwujudan 
agama yang rahmatan li al-alamin. Islam dan hak asasi manusia didasarkan pada Al-Qur'an dan Hadis, di dalamnya terkandung prinsip-prinsip dasar tentang persamaan, kebebasan yang bertanggung jawab dan toleransi dengan sesama manusia. Prinsip persamaan bermakna bahwa Islam memandang manusia sebagai makhluk yang paling sempurna diantara makhluk lain ciptaan Allah yang memiliki harkat, martabat, serta derajat yang setara di hadapan Allah. Prinsip kebebasan dalam Islam merupakan kebebasan namun di satu sisi dia memiliki hak dan di sisi lain dia mempunyai tanggung jawab. Prinsip toleransi dalam Islam mengajarkan bahwa sesama manusia haruslah saling hormat menghormati karena pada dasarnya manusia sama di hadapan Allah kecuali tingkat ketakwaan.

Ketiga, materi hak asasi manusia dalam piagam madinah merupakan ketetapan hukum yang dijabarkan dalam Piagam Madinah sekaligus memberikan contoh aplikasi hak asasi manusia yang berlandaskan nilai-nilai keislaman. Piagam Madinah sendiri merupakan susunan naskah perjanjian resmi buah dari pemikiran Rasullullah untuk menghentikan pertentangan sengit antara Bani 'Aus dan Bani Khazraj di Madinah sekitar tahun 622 M. Perjanjian itu mengundang suku-suku dan kaum-kaum yang dianggap berpengaruh di Kota Madinah, antara lain kaum muslim (golongan Ansor dan Muhajirin), yahudi, dan penyembah berhala. Perjanjian itu memuat seperangkat hak dan kewajiban masing-masing kaum tersebut untuk menciptakan kehidupan bermasyarakat yang damai dan tenteram. Melalui perjanjian itu juga, Rasullullah mempersatukan kehidupan bermasyarakat di Madinah yang plural. Adapun substansi piagam Madinah menurut Sudjana (2003), adalah monoteisme, persatuan dan kesatuan, persamaan dan keadilan, kebebasan beragama, bela negara, pengakuan dan pelestarian adat kebiasaan (hal. 89). Sukardja (2012) kemudian melengkapi substansi tersebut dengan prinsip supremasi syariat, dan politik damai dan proteksi internal (hal. 114). Substansi piagam madinah tersebut kemudian ditafsirkan para ulama menjadi 5 prinsip yaitu: Hifdzu al-Din (penghormatan atas kebebasan beragama), Hifdzu alMal (penghormatan atas harta benda), Hifdzu al-Nafs wa al-'Ird (penghormatan atas jiwa, hak hidup dan kehormatan individu), Hifdzu al-'AqI (penghormatan atas kebebasan berfikir), Hifdzu alNasl (keharusan untuk menjaga keturunan) (Jauhar, 2009)

\section{Penilaian dan Perbaikan Ahli/ Pakar}

\section{Penilaian dan Perbaikan Ahli Isi dan Sajian Materi}

Pada aspek kelayakan isi, diperoleh skor 75 dari 7 item pertanyaan dari tiga orang ahli. Berdasarkan perolehan tersebut maka pakar/ ahli menilai kelayakan isi dan sajian materi rata-rata 3,57 atau $89 \%$. Aspek materi pendukung/ rujukan memperoleh skor 11 dari 3 item pertanyaan, berdasarkan perolehan tersebut pakar atau ahli menilai kelayakan rata-rata 3,67 atau $91 \%$. Aspek kelayakan penyajian memperoleh skor 8 dari 2 item pertanyaan, berdasarkan perolehan tersebut pakar atau ahli menilai kelayakan rata-rata 4 atau $100 \%$. Sehingga disimpulkan buku ajar layak digunakan dengan revisi perbaikan.

Pada aspek kesesuaian pemakaian bahasa yang komunikatif, diperoleh skor 7 dari 2 item pertanyaan. Berdasarkan perolehan tersebut maka pakar/ ahli kebahasan menilai kelugasan, ketepatan, dan kebakuan bahasa rata-rata 3 atau $75 \%$. Aspek kesesuaian pemakaian bahasa yang komunikatif memperoleh skor 11 dari 3 item pertanyaan, berdasarkan perolehan tersebut pakar atau ahli menilai kelayakan rata-rata 3,5 atau 87,5 \%. Sehingga disimpulkan buku ajar layak digunakan dengan revisi perbaikan bahasa.

Pada aspek kelayakan desain/ bentuk buku, diperoleh skor 11 dari 3 item pertanyaan. Berdasarkan perolehan tersebut maka pakar/ ahli Desain Grafis menilai kelayakan desain/ bentuk buku rata-rata 3, 67 atau 91, 75 \%. Aspek kelayakan sampul/ cover memperoleh skor 18 dari 5 
item pertanyaan, berdasarkan perolehan tersebut pakar atau ahli desain grafis menilai kelayakan rata-rata 3,6 atau 90 \%. Aspek kelayakan desain isi buku memperoleh skor 18 dari 5 item pertanyaan, berdasarkan perolehan tersebut pakar atau ahli desain grafis menilai kelayakan ratarata 3,6 atau $90 \%$. Sehingga disimpulkan buku ajar layak digunakan dengan revisi perbaikan design grafis.

Pada aspek ketertarikan materi, diperoleh skor 15 dari 4 item pertanyaan per 30 mahasiswa. Berdasarkan perolehan tersebut maka mahasiswa menilai ketertarikan materi rata-rata 3,75 atau 93,75\%. Aspek tingkat kesulitan materi memperoleh skor 10 dari 3 item pertanyaan, berdasarkan perolehan tersebut mahasiswa menilai kelayakan rata-rata 3,33 atau 83,33\%. Aspek kemanfaatan memperoleh skor 8 dari 2 item pertanyaan, berdasarkan perolehan tersebut mahasiswa menilai kelayakan rata-rata 4 atau $100 \%$. Aspek bahasa memperoleh skor 8 dari 2 item pertanyaan, berdasarkan perolehan tersebut mahasiswa menilai kelayakan rata-rata 4 atau $100 \%$. Sehingga disimpulkan buku ajar layak digunakan dengan revisi.

\section{Simpulan}

Pengembangan bahan ajar Pendidikan Kewarganegaraan di PTKIN dapat diintegrasikan dengan nilai-nilai syariat Islam sehingga dapat menunjang perkuliahannya di Perguruan Tinggi Keagamaan Islam yang khas dengan keislamannya. Adapun materi-materi yang dapat terintegrasi antara lain Negara dan Sistem Pemerintahan, Demokrasi, dan Hak Asasi Manusia. Kelayakan isi dan sajian materi memperoleh persentase 93,3\%, kelayakan aspek kebahasaan memperoleh persentase $81,25 \%$, kelayakan desain grafis memperoleh persentase $90,6 \%$, dan aspek penilaian mahasiswa memperoleh persentase $94,27 \%$. Berdasarkan penilaian tersebut maka rata-rata kelayakan adalah $89,85 \%$

\section{Ucapan Terima Kasih}

Tulisan ini merupakan hasil penelitian yang memperoleh dukungan finansial dari DIPA IAIN Metro Tahun 2018 berdasarkan kontrak nomor B/04/LPPM/2018. Oleh karena itu, penulis menghaturkan ucapan terima kasih kepada Rektor IAIN Metro beserta seluruh jajarannya khususnya Ketua Lembaga Penelitian Dan Pengabdian Kepada Masyarakat atas dukungan dan segala pelayanan administrasi yang prima bagi penulissehingga penelitian terselesaikan tepat waktu. Penghargaan yang setinggi-tingginya penulis haturkan kepada seluruh narasumber dan mahasiswa yang menjadi subjek ujicoba atas keleluasaan waktu yang diberikan sehingga penelitian menjadi lebih baik.

\section{Referensi}

Arif, D. B., \& Aulia, S. S. (2017). Studi tentang negara Pancasila sebagai Darul Ahdi Wa Syahadah untuk penguatan materi pembelajaran Pendidikan Kewarganegaraan di Universitas Ahmad Dahlan. Jurnal Civics: Media Kajian Kewarganegaraan, 14(2), 206-217.

Bajunid, I. A. (2008). The building of a nation and ideas of nationhood: Citizenship education in Malaysia. In Citizenship curriculum in Asia and the Pacific (hal. 127-146). Springer.

Chamim, A. I. (2003). Civic education: Pendidikan kewarganegaraan menuju kehidupan yang demokratis dan berkeadaban. Majelis Pendidikan Tinggi Penelitian dan Pengembangan PP Muhammadiyah, LP3M UMY, dan The Asia Foundation.

Direktorat Jenderal Pembelajaran dan Kemahasiswaan. (2016). Pendidikan Kewarganegaraan untuk Perguruan Tinggi. Direktorat Jenderal Pembelajaran dan Kemahasiswaan Kementerian Riset, Teknologi, dan Pendidikan Tinggi.

Fearnley-Sander, M., \& Yulaelawati, E. (2008). Citizenship discourse in the context of decentralisation: The case of Indonesia. In Citizenship curriculum in Asia and the Pacific (hal. 111-126). Springer. 
Tubagus Ali Rachman Puja Kesuma, Sri Handayana, Deri Cicira. Pengembangan bahan ajar kewarganegaraan di perguruan tinggi keagamaan Islam

Hadin, A. F., \& Fahlevi, R. (2016). Desain bahan ajar pendidikan kewarganegaraan berbasis pendidikan anti korupsi di perguruan tinggi. Jurnal Moral Kemasyarakatan, 1(2), 162-172. https://doi.org/10.21067/jmk.v1i2.1533

Kementerian Riset Teknologi dan Pendidikan Tinggi. (2017). Panduan bimbingan teknis dosen MKU Kewarganegaraan. Direktorat Jenderal Pembelajaran dan Kemahasiswaan Kementerian Riset Teknologi dan Pendidikan Tinggi.

Kerr, D. (1999). Citizenship education in the curriculum: An international review. The School Field, X(3-4), 5-32.

Kesuma, T. (2017). Pola integrasi dalam masyarakat majemuk (Studi ketahanan sosial di Kecamatan Kotagajah, Lampung). JIPSINDO, 4(2), 184-212. https://doi.org/10.21831/jipsindo.v4i2.17576

Meihui, L. (2004). A society in transition: The paradigm shift of civic education in Taiwan. In W. O. Lee, D. L. Grossman, K. J. Kennedy, \& G. P. Fairbrother (Ed.), Citizenship Education in Asia and the Pacific: Concept and Issues (hal. 97-117). Springer.

Natsir, M. (1961). Capita selecta. Sumur.

Sadzali, M. (1990). Islam dan tata negara. UI Press.

Sudjana, E. (2003). HAM dalam perspektif Islam. Nuansa Madani.

Sugiyono. (2012). Metode penelitian kuantitatif kualitatif dan R\&D. Alfabeta.

Sukardja, A. (2012). Piagam Madinah dan UUD NRI 1945. Sinar Grafika.

Winarno. (2015). Pendidikan Kewarganegaraan untuk perguruan tinggi. Ombak.

Winataputra, U. S. (2001). Jatidiri pendidikan kewarganegaraan sebagai pendidikan demokrasi. Disertasi. Sekolah Pascasarjana Universitas Pendidikan Indonesia.

Zainuddin, M. (2011). Islam dan demokrasi. Yayasan Abad Demokrasi. 